\title{
Biogeochemical nutrient cycles and nutrient management strategies
}

\author{
Daniel J. Conley \\ Department of Marine Biology and Microbiology, National Environmental Research Institute, P.O. Box 358, DK- \\ 4000 Roskilde, Denmark \\ E-mail:dco@dmu.dk
}

Key words: eutrophication, nutrient limitation, nitrogen, phosphorous, silicate

\begin{abstract}
Nutrient loading by riverine input into estuarine systems has increased by 6-50 times for the N load from pristine conditions to present, whereas a 18-180 times increase has been observed in the P load. Reductions in the ratio of $\mathrm{N}$ to $\mathrm{P}$ delivery has also occurred with time. In a review of nutrient limitation in estuarine systems, it is shown that many estuarine systems display $\mathrm{P}$ limitation in the spring, switching to $\mathrm{N}$ limitation in the summer with some estuaries displaying dissolved silicate limitation of the spring diatom bloom. Historical and recent changes in nutrient loading and their effect on nutrient limitation have intensified the debate on the control of nutrient delivery to estuaries from both agricultural and point sources, and as to what nutrient ( $\mathrm{N}$ or $\mathrm{P}$ ) should be managed for in estuarine systems. It is hypothesized that potential reductions in $\mathrm{P}$ may help oxygen depletion especially in deep estuaries and reduce fast growing macrophytes such as Ulva sp., although $\mathrm{P}$ reductions probably will have little effect on summer chlorophyll concentrations, an important recreational management goal. Reductions in $\mathrm{N}$ loading should reduce summer chlorophyll concentrations and improve the conditions for submerged aquatic vegetation and thus improve ecosystem functioning. Finally, if only P reductions are pursued, that is if we are able to reduce $\mathrm{P}$ such that it is limiting year around in estuarine systems, it is likely that the export of $\mathrm{N}$ from estuarine systems would increase to the bordering N-limited marine systems, thus only exporting the problem of enhanced production with eutrophication.
\end{abstract}

\section{Introduction}

The load of nutrients to aquatic systems has greatly increased with time through human activity. As a consequence of this increased nutrient loading, detrimental effects have been observed on the health of coastal ecosystems leading to, amongst other things, excess accumulations of phytoplankton biomass (Malone et al., 1986), episodes of noxious blooms, reductions in aquatic macrophyte communities (Sand-Jensen \& Borum, 1991; Duarte, 1995) and the depletion of dissolved oxygen in bottom waters (Malone et al., 1986).

An important question facing us as scientists and as advisors to the management community is the role of nutrients ( $\mathrm{N}, \mathrm{P}$ and $\mathrm{Si}$ ) in limiting system production, especially which nutrient limits phytoplankton production. While it is generally accepted that $\mathrm{P}$ limits freshwater systems (Schindler, 1974) and N limits marine systems (Nixon et al., 1996), problems arise in what nutrient to manage for in estuarine systems since these systems can show both $\mathrm{N}$ and $\mathrm{P}$ limitation at varying temporal and spatial scales (D'Elia et al., 1986; Malone et al., 1996).

In this paper, I will evaluate the changes that have occurred in nutrient loading to estuaries with time, I will review the evidence for nutrient limitation in aquatic ecosystems focusing on estuarine systems, I will examine the differences in biogeochemical cycles that may account for differences in what nutrient is limiting and finally discuss the consequences of different nutrient management strategies to estuarine systems.

\section{Nutrient loading}

It is widely accepted that increases in nutrient loading have taken place from anthropogenic activities, however, the magnitude of that increase is poorly known. 
The construction of well-constrained nutrient budgets for the present day is possible for many aquatic ecosystems given the availability of information, however, modeling must be used to estimate nutrient budgets under pristine conditions. An excellent example of reconstructing historical nutrient loads is provided by Chapra (1977) where the P inputs to the North American Great Lakes were partitioned into their various sources, e.g. from the atmosphere, from land runoff, from direct inputs from anthropogenic activities, and from upstream sources, and the changes in inputs with time were estimated (Figure 1). The source proportioning method utilized by Chapra (1977) provided an important tool to evaluate historical changes in nutrient loading in the Great Lakes in order to determine the impact of man's activities on P loading through time.

Although modern day nutrient budgets are available for many estuarine and coastal systems (e.g. Nixon et al., 1996), few estimates are available to compare present day nutrient loads to those under pristine conditions. I have assembled previously made estimates of nutrient loading for four different estuarine systems (Figure 2) for pristine conditions, at the turn of the last century, and present day nutrient loads. Because of the large range in absolute nutrient loading, the nutrient loading has been normalized to watershed area to allow for the comparison of the intensity of nutrient loading from the land to different systems. It is clear that the load of nutrients to aquatic systems has increased greatly with time through human activity. The estimates presented here range from a 18 to 180 times increase in the amount of $\mathrm{P}$ and a 6 to 50 times increase in the amount of $\mathrm{N}$ from pristine conditions to present. Although determination of the exact amount of nutrients under 'pristine conditions' is problematic as most modern analogs of 'pristine' systems are perturbed by atmospheric deposition, the uncertainty in this estimate, however, is small relative to the large increases in loading observed between pristine conditions and present. Relative to conditions at the turn of the century, $P$ loads in these systems have increased by approximately $2-6$ times and $\mathrm{N}$ loads have increased $1.5-4.5$ times (Figure 2).

It is likely that exports of $\mathrm{N}$ and $\mathrm{P}$ from pristine watersheds were also different in chemical composition and contained a different relative N:P ratio (Figure 3 ). In anthropogenically undisturbed systems efficient nutrient recycling processes retain most of the inorganic compounds and nutrient export is primarily in the form of organic compounds. For example, $\mathrm{N}$ exports

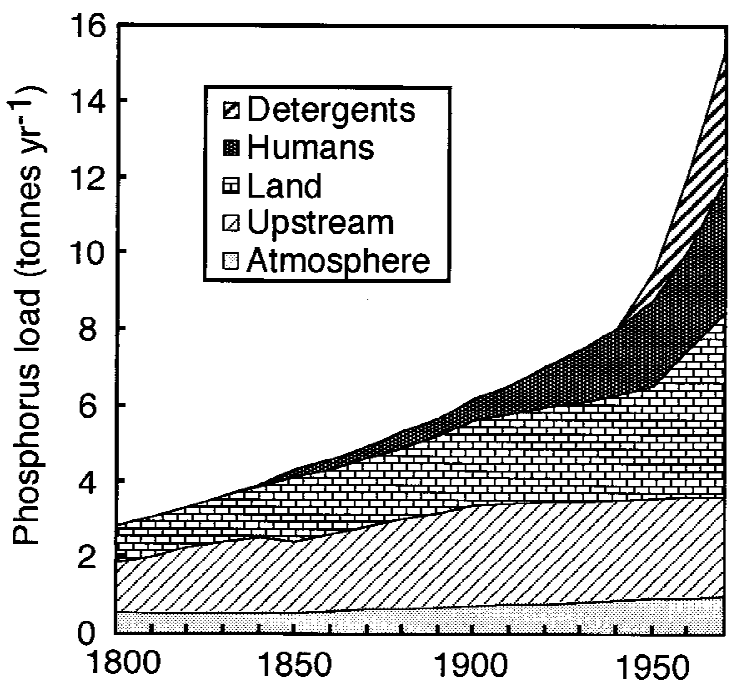

Figure 1. Historical loads of total $\mathrm{P}$ from various sources to the North American Great Lakes as determined from a source-partitioning model. The figure is redrawn from Chapra (1977).

from undisturbed Chilean watersheds occur primarily as dissolved organic nitrogen (Hedin et al., 1995). Alteration in the export of dissolved inorganic nutrients results in changes in nutrient ratios (Figure 3) with a lower N:P ratio observed in anthropogenically disturbed watersheds (Billen et al., 1991). Changes in the export of Si with anthropogenic activities is poorly known, especially in terms of changes in production of dissolved silicate through weathering reactions. It is clear, however, that reductions in Si delivery to the coastal zone have occurred with the enhanced retention of $\mathrm{Si}$ as diatoms are trapped in lakes and behind dams (Conley et al., 1993; Billen \& Garnier, 1997)

\section{Nutrient limitation}

Considerable effort has been put into determining the role of nutrients ( $\mathrm{N}, \mathrm{P}$ and $\mathrm{Si}$ ) in limiting system production, especially which nutrient limits phytoplankton production. A hierarchy of experimental approaches (sensu Hecky \& Kilham, 1988) has been used to assess the response of phytoplankton to nutrient additions across scales from small-scale bioassays, mesocosms, cross-system comparisons, to wholesystem fertilization. In addition, a variety of specific indicators have been used to assess nutrient limitation, including determination of the physiological state of phytoplankton, inorganic nutrient stoichiometry and 

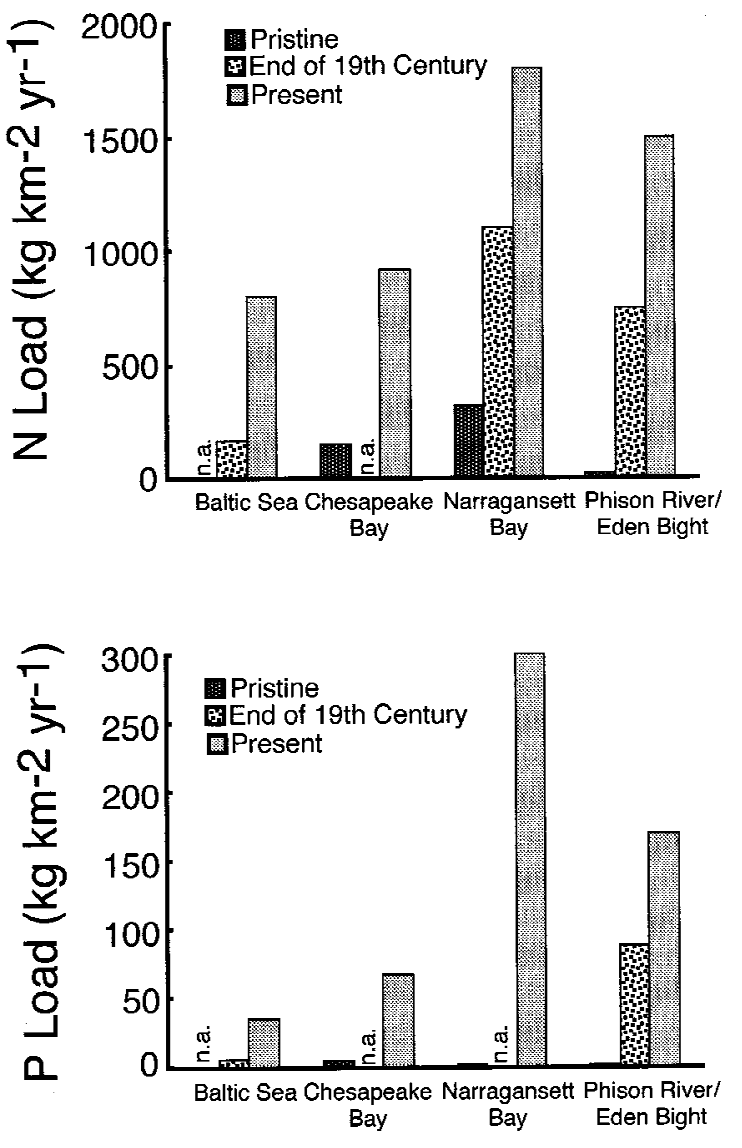

Figure 2. (A) The annual $\mathrm{N}$ load and (B) the annual P load per unit of watershed area $\left(\mathrm{kg} \mathrm{km}^{-2} \mathrm{y}^{-1}\right)$ for various estuarine systems under pristine conditions, at the turn of the last century and at present. Data are from Larsson et al. (1985) for the Baltic Sea with updated loading calculations of Stålnacke et al. (1998), Boynton et al. (1995) for Chesapeake Bay, Nixon $(1995,1997)$ for Narragansett Bay, and Billen \& Garnier (1997) for the hypothetical system of Phison River/Eden Bight. All loads are for total $\mathrm{N}$ and total P except for Narragansett Bay which are only inorganic nutrient concentrations. n.a. is data not available.

concentration, composition ratios, and various measurements of phytoplankton growth. The purpose here is to only briefly detail the evidence for nutrient limitation in freshwater and marine environments and then to focus on the results of numerous recent studies determining nutrient limitation in estuarine environments. Although the focus of this review is on nutrients, it should not be forgotten that light limitation is also one of the major factors regulating the growth of phytoplankton in aquatic systems (Cloern, 1998). In addition, the focus on a single nutrient is in some ways problematic, as the largest response to nutrient addition usually occurs when multiple nutrients are added.

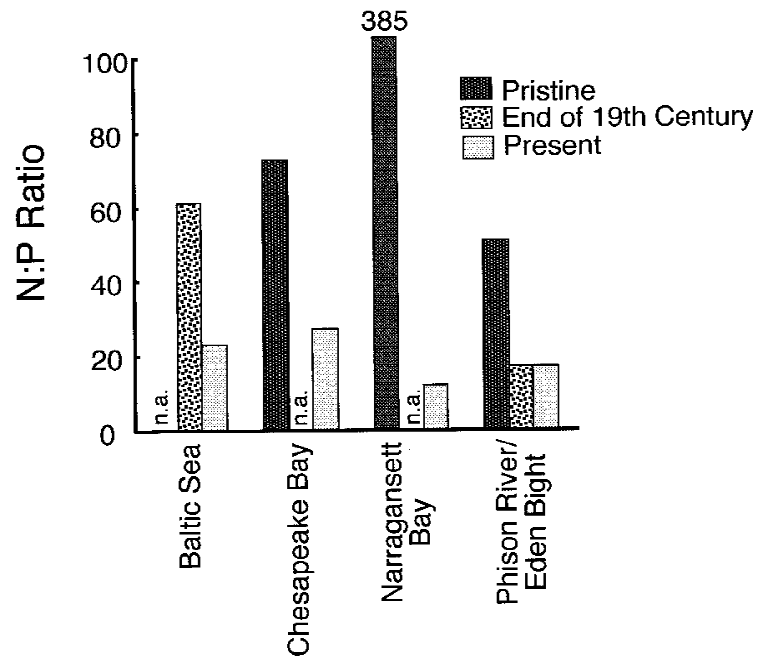

Figure 3. The N:P loading ratio for different estuarine systems under pristine conditions, at the turn of the last century and at present. The data are the same used in Figure 2. n.a. is data not available.

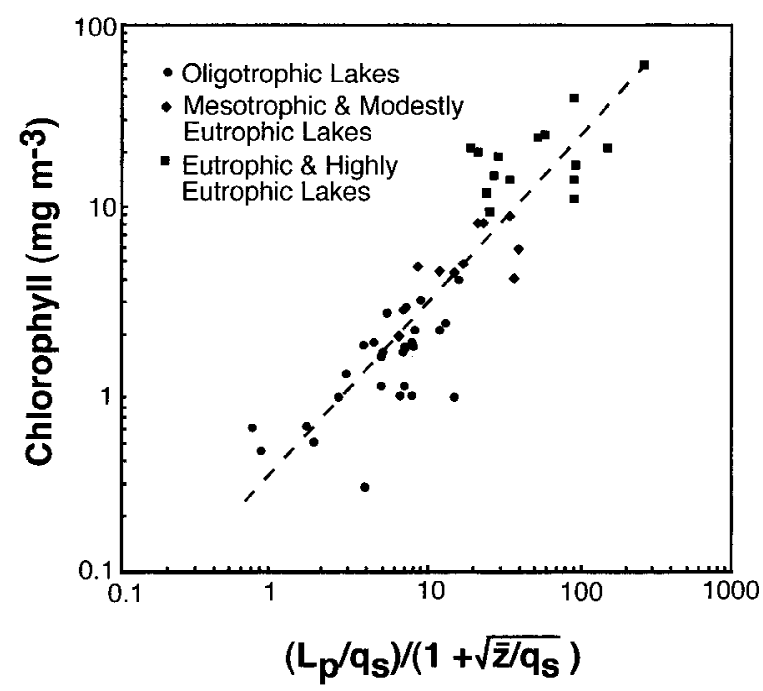

Figure 4. Statistical relationships between average epilimnetic chlorophyll concentration and phosphorus loading characteristics (from Vollenweider, 1976) in a variety of freshwater systems. $\mathrm{L}_{\mathrm{p}}$ is phosphorus loading $\left(\mathrm{g} \mathrm{m}^{-2} \mathrm{~h}^{-1}\right), \mathrm{q}_{\mathrm{s}}$ is hydraulic loading $\left(\mathrm{m} \mathrm{y}^{-1}\right.$ $\mathrm{m}^{-3}$ of lake area), and $\mathrm{z}$ is mean depth $(\mathrm{m})$. Figure is redrawn from Hecky \& Kilham (1988).

In freshwaters, there is a general consensus that $\mathrm{P}$ is often most limiting to phytoplankton growth (Hecky \& Kilham, 1988; Howarth, 1988), although during summer, when dissolved inorganic nutrients are depleted from the photic zone, a response is often elicited with $\mathrm{N}$ as well as $\mathrm{P}$ (Elser et al., 1990). The most compelling evidence that $\mathrm{P}$ is limiting in freshwaters came from the whole lake experiments by Schindler (1974). 


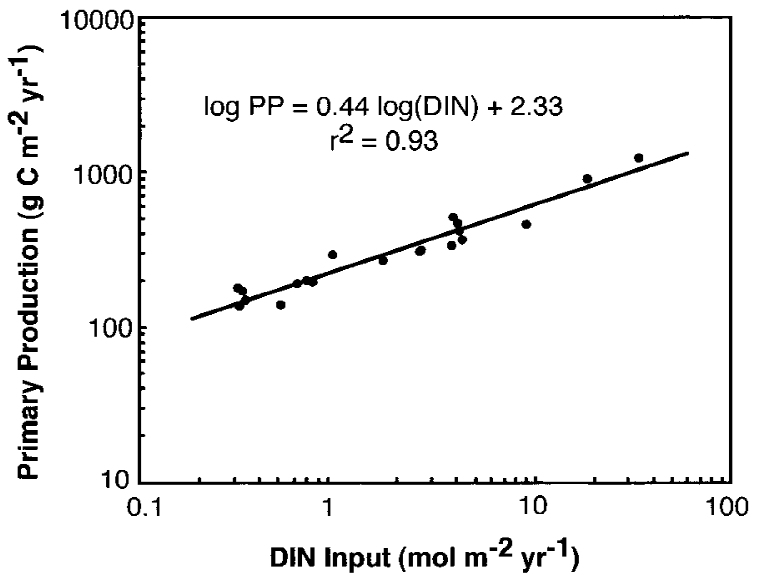

Figure 5. Primary production by phytoplankton $\left({ }^{14} \mathrm{C}\right.$ uptake) as a function of the estimated rate of input of dissolved inorganic nitrogen (DIN) per unit area in a variety of marine ecosystems. Figure is redrawn from Nixon et al. (1996).

Visually dramatic differences in algal blooms were seen in lake 226 that was separated by an artificial curtain and enriched with N, C and P, but substantial algal blooms were not observed when enriched with only $\mathrm{N}$ and C. Cross-system comparisons, best exemplified by Vollenweider (1976), where the dependence of average epilimnetic chlorophyll concentrations were significantly related to phosphorus loading characteristics, suggested that lakes in general are P-limited (Figure 4). Similar P-chlorophyll relationships have been observed by numerous authors (see Prairie et al., 1989).

In marine waters, the general consensus has been that $\mathrm{N}$ is often most limiting to phytoplankton growth, although the evidence for $\mathrm{N}$ limitation was not as strong as the evidence for $\mathrm{P}$ limitation in freshwaters when the most recent reviews of nutrient limitation were written, e.g. Hecky \& Kilham (1988) and Howarth (1988). The classic study demonstrating that $\mathrm{N}$ is most limiting in marine waters by Ryther \& Dunstan (1971), although often cited, has been criticized by many (e.g. Oviatt et al., 1995). More recent, ecosystem-level nutrient limitation experiments are in support of the evidence that $\mathrm{N}$ is the nutrient most limiting to primary production in marine systems (Oviatt et al., 1995). In some of the early cross-system comparisons for coastal marine environments (Boynton et al., 1982), $\mathrm{N}$ was suggested as more important than $\mathrm{P}$, although statistically significant relationships were not found. However, the recent compilation by Nixon et al. (1996) also supports $\mathrm{N}$ to be the limiting nutrient in marine waters (Figure 5).
In estuarine systems, the question of nutrient limitation has aroused much debate. D'Elia et al. (1986) first demonstrated that estuaries can switch from $\mathrm{P}$ limitation in the spring to $\mathrm{N}$ limitation during summer (Figure 6). This result was extremely controversial at the time as it carried with it enormous economic implications for nutrient management strategies in Chesapeake Bay. The responsible authorities wanted to limit only $\mathrm{P}$ inputs to the system and not address N loading (D’Elia, 1987). In the last decade, numerous studies have been completed in estuarine systems that demonstrate that the switching nutrient limitation observed by D'Elia is not a phenomena restricted to Chesapeake Bay, but is a common feature in estuarine systems. I have compiled data for different estuarine systems that exhibit seasonal switching between spring $\mathrm{P}$ limitation and summer $\mathrm{N}$ limitation (Table 1). Of the systems presented here, the $\mathrm{P}$ limitation observed during spring is sometimes weaker than the response observed during summer when a much stronger response is observed to $\mathrm{N}$ limitation, for example see Figure 6.

It should be noted that not all estuarine systems display this seasonal switching in nutrient limitation. For example, the low salinity Bothnian Bay in the northern Baltic Sea is P-limited year around (Andersson et al., 1996), whereas the higher salinity open waters of the Baltic display N-limitation throughout (Granéli et al., 1990). It is only where freshwater enters these Baltic coastal systems, as in the Himmerfjärden Estuary (Elmgren \& Larsson, 1977) and in the Gulf of Riga (Maestrini et al., 1997), where seasonal switches in nutrient limitation occurs. The various systems compiled in Table 1 cover a range of salinity, nutrient loading, loading ratios and nutrient concentrations. The common factor with these various estuarine systems is that all systems have a significant quantity of seasonal freshwater input entering the system. Although the strongest $\mathrm{P}$ limitation tends to occur in oligohaline portions of the estuaries closer to the freshwater end-member, P limitation is also observed at higher salinities (Malone et al., 1996).

Diatom production can be seasonally limited by dissolved silicate concentrations in a number of estuarine systems (Table 1). An example is the Chesapeake Bay where dissolved silicate concentrations and loading determine the magnitude of the diatom bloom during the spring, causes the collapse of the spring diatom bloom and leads to changes in floristic composition of phytoplankton communities (Conley \& Malone, 1992) allowing for diatoms to be replaced by 
Table 1. Estuaries exhibiting seasonal shifts in nutrient limitation with spring $\mathrm{P}$ limitation and summer $\mathrm{N}$ limitation

\begin{tabular}{ll}
\hline Estuary & Reference \\
\hline Baltic Sea & \\
Himmerfjärden Estuary, Sweden & Granéli et al. (1990), Elmgren \& Larsson (1997) \\
Gulf of Riga, Latvia & Maestrini et al. (1997) \\
Roskilde Fjord, Denmark & Pedersen \& Borum (1996) \\
Bay of Brest, France ${ }^{a}$ & Del Amo et al. (1997) \\
Chesapeake Bay, U.S.A. ${ }^{a}$ & \\
Mainstem & Malone et al. (1996) \\
Patuxent River Estuary & D'Elia et al. (1986) \\
York River Estuary & Webb (1988) \\
Rhode River Estuary & Gallegos \& Jordan (1997) \\
Delaware Estuary, U.S.A. & Pennock \& Sharp (1994) \\
Neuse River Estuary, U.S.A. & Mallin \& Paerl (1994) \\
\hline
\end{tabular}

${ }^{a}$ Systems displaying seasonal dissolved silicate limitation.

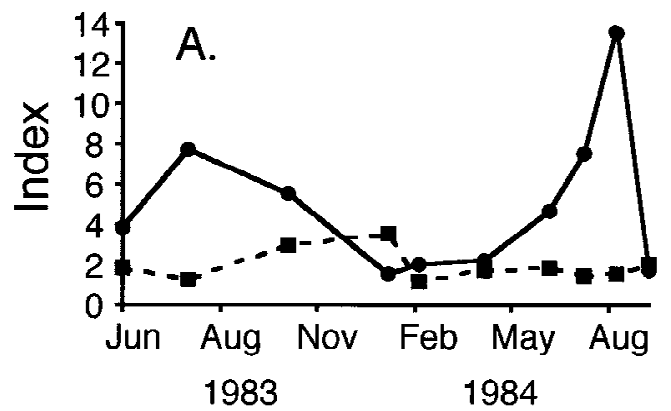

\section{$-\rightarrow-$ P limitation $\longrightarrow$ N limitation}

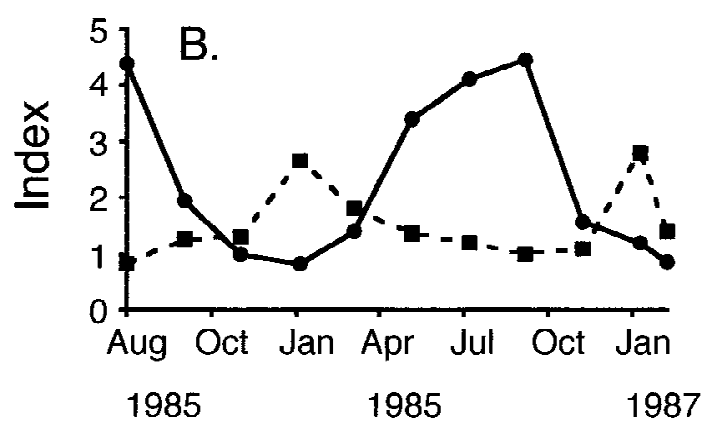

Figure 6. Nutrient limitation index (treatment chlorophyll:contol chlorophyll) for the (A) Patuxent River estuary and (B) York River estuary, tributaries to the Chesapeake Bay. Figure is redrawn from Webb (1997).

species not requiring dissolved silicate for growth. In the Bay of Brest, dissolved silicate limitation appears to be a relatively recent phenomena first observed in the 1990s, whereas prior to this time the Bay of Brest was primarily $\mathrm{N}$ limited (Del Amo et al., 1997).

\section{Biogeochemical cycles}

Explanations regarding why $\mathrm{P}$ is the primary limiting nutrient in freshwaters and $\mathrm{N}$ is the primary limiting nutrient in marine systems revolve around differences in the biogeochemical cycles of $\mathrm{N}$ and $\mathrm{P}$. Three aspects of $\mathrm{N}$ and $\mathrm{P}$ biogeochemistry focusing on net gains or losses can be considered:

1. losses of $\mathrm{N}$ from denitrification;

2. the extent to which $\mathrm{N}$ deficiency can be made up for by $\mathrm{N}_{2}$ fixation; and

3. the sediment regeneration of $P$.

As will be shown below, it is the sediment regeneration of $\mathrm{P}$ that probably accounts for the seasonal switching of limiting nutrients in estuarine systems.

In a comparison of freshwater, brackish and marine ecosystems Seitzinger (1988) noted small differences in rates of denitrification, however, there were no large differences in rates of denitrification between freshwater and marine environments. While denitrification is certainly an important loss process for $\mathrm{N}$ in marine systems (Nixon et al., 1996), $\mathrm{N}$ is not lost from marine systems at considerably higher rates than freshwater systems accounting for marine systems to be $\mathrm{N} \mathrm{lim-}$ ited. Seasonal changes in rates of denitrification are observed in estuarine systems with the highest rates often observed during winter and spring (Rysgaard et al., 1995) when water column $\mathrm{NO}_{3}{ }^{-}$concentrations are at their seasonal maxima. Thus, a major loss term in the biogeochemical cycle of $\mathrm{N}$ (Nixon et al., 1996) is minimized during the summer when $\mathrm{N}$ limitation in the water column is strongest, as $\mathrm{NO}_{3}{ }^{-}$is usually depleted from the water column and denitrific- 


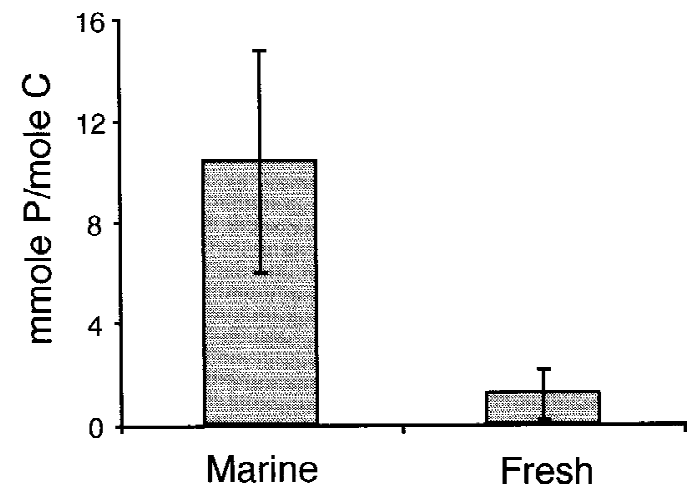

Figure 7. Average (with $95 \%$ confidence limits) of relative phosphorus release for brackish and coastal marine systems (Marine) and from freshwater systems (Fresh). The low relative release rate in freshwater systems suggests that in these systems sediments immobilize a large fraction of the $\mathrm{P}$ released from organics during decomposition. In most marine and brackish systems, essentially all of the remineralized $\mathrm{P}$ is returned to the water column. Figure is redrawn from Caraco et al. (1990).

ation is limited by coupled nitrification-denitrification processes.

The capacity to which deficits in $\mathrm{N}$ can be made up for by $\mathrm{N}_{2}$ fixation is much greater in freshwater systems, whereas $\mathrm{N}_{2}$ fixation is not generally important in marine systems (Howarth et al., 1988). If a lake has a low $\mathrm{N}$ load and concentration relative to $\mathrm{P}$, deficits in $\mathrm{N}$ concentrations can often be made up for through $\mathrm{N}_{2}$ fixation (Schindler, 1974) allowing for $\mathrm{P}$ to be controlling the accumulation of biomass even though $\mathrm{P}$ may initially be in excess relative to $\mathrm{N}$. Although there are still many questions concerning the mechanism as to why $\mathrm{N}_{2}$ fixation is not common in marine systems (Paerl et al., 1995; Howarth et al., 1995), this difference in biogeochemical cycling can have an important impact upon which nutrient is limiting in freshwater and marine environments.

One of the greatest differences in nutrient biogeochemical cycles between freshwater and marine systems occur in $\mathrm{P}$ biogeochemistry with the ability of freshwater systems to retain $\mathrm{P}$ in sediments through interactions with $\mathrm{Fe}$. By contrast, in marine systems nearly all the $\mathrm{P}$ deposited in sediments is remineralized on an annual basis (Caraco et al., 1990) and returned to the overlying water (Figure 7). Caraco et al. (1989) also observed that $\mathrm{P}$ release from sediments is highly dependent upon sulfate concentrations, which can be used as a surrogate for salinity. Therefore, it is the preferential loss of $\mathrm{P}$ in freshwater systems as compared to marine environments allowing for $\mathrm{P}$ to be scarcest and therefore the limiting nutrient.

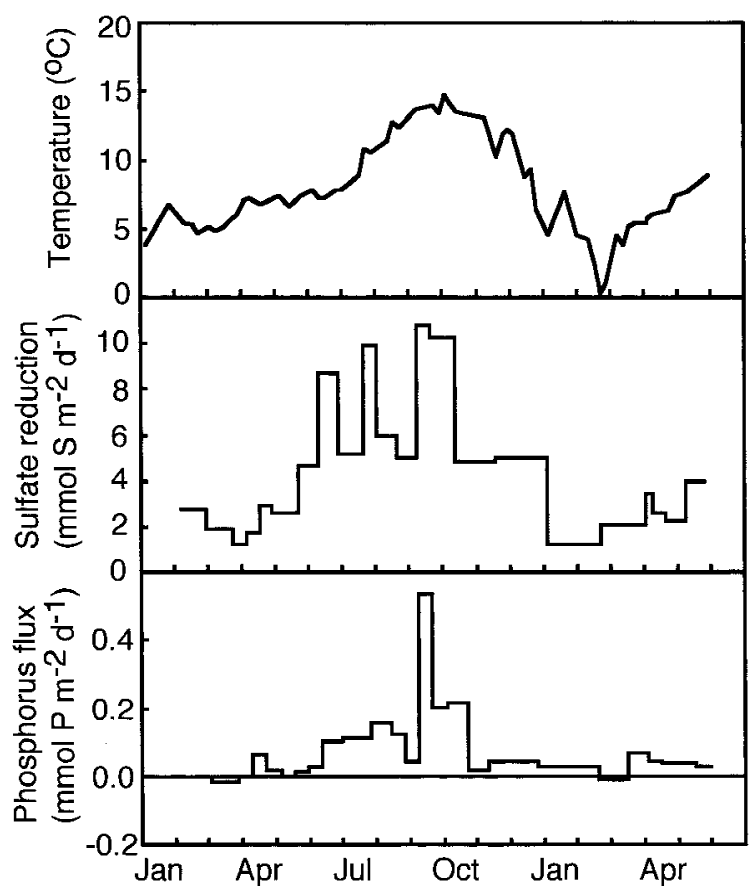

Figure 8. Seasonal variation in (A) temperature of bottom water, (B) sulfate reduction rates for the upper $10 \mathrm{~cm}$ of sediment, (C) and phosphorus flux from the sediments of Aarhus Bight. Figure is redrawn from Jensen et al. (1995).

The seasonal switching in nutrient limitation observed in estuaries can be explained by the seasonal pattern in $\mathrm{P}$ release from sediments. $\mathrm{P}$ concentrations in estuaries are often found to be highest during summer corresponding to a strong temperature dependent release of P (Nixon et al., 1980). The majority of $P$ release occurs during summer (Figure 8) and is associated with changes in Fe cycling with sulfate reduction (Jensen et al., 1995). When sulfate reduction rates are low, there is a seasonal storage of $\mathrm{P}$ in sediments occurring during winter and spring mainly as Fe-associated P (Jensen et al., 1995). The P that accumulates during winter and spring is subsequently released when the temperature dependent sulfate reduction rates increase releasing Fe bound sulfate and $\mathrm{Fe}$-associated P. The release of dissolved silicate from the regeneration of diatom frustules is also a temperature dependent process with the highest concentrations of dissolved silicate often observed in estuaries during the summer (Conley \& Malone, 1992). The high rates of regeneration and sediment release observed during summer for both dissolved inorganic phosphorus and dissolved silicate, brings high concentrations back into the overlying water, creating an internal source of nu- 
trients, making it is less likely that $\mathrm{P}$ or $\mathrm{Si}$ will be limiting in estuaries during summer.

\section{Consequences for management strategies}

Given the paradigm that $\mathrm{P}$ is limiting in freshwaters and that $\mathrm{N}$ is limiting in marine waters, an important question arises as to what is the best course of action to take to reduce nutrient loads and improve the health of estuaries given that many estuaries show seasonal switches in the most limiting nutrient. Many management strategies focus primarily on $\mathrm{P}$ because that is the easiest nutrient to address first in high nutrient loaded systems by construction of advanced sewage treatment plants. Therefore, I will also explore the question of what are the consequences for estuarine systems by reductions in only $\mathrm{P}$ loading, or by reductions in only $\mathrm{N}$ loading.

\section{Phosphorus}

$\mathrm{P}$ appears to be an important limiting nutrient in many estuarine systems during spring (Table 1). It is rare that $\mathrm{P}$ limitation is observed year around. Year around $\mathrm{P}$ limitation is found to occur only in estuaries with high freshwater inputs of low dissolved inorganic phosphorus concentrations, for example in the River Göta älv estuary draining the largest freshwater lake in Sweden (Selmer \& Rydberg, 1993). Reductions in P should have its largest effect on spring production. It is well established that spring is the most important time period of the year for seasonal deposition of organic matter to the sediments (Wassmann, 1991). Reductions in $\mathrm{P}$ loading and increasing the occurrence of $\mathrm{P}$ limitation, thus may lead to reductions in the seasonal deposition of organic matter. For deeper estuaries, such as Chesapeake Bay where spring $\mathrm{P}$ limitation is prevalent (Malone et al., 1996) and it is the organic matter produced during spring that fuels summer anoxia (Malone et al., 1986), reductions in P loading has the potential to improve summer oxygen conditions.

One of the most effective measures in reducing $\mathrm{P}$ loading is the control of point sources, especially the advanced treatment for the removal of $\mathrm{P}$ from sewage. In Danish estuaries (Odense Fjord \& Roskilde Fjord) that have experienced large reductions in $\mathrm{P}$ loading and modest reductions in $\mathrm{N}$ loading with construction of advanced sewage treatment plants (Kaas et al., 1996), there has been a consequent reduction in the fast growing macrophyte Ulva lactuca. Although in Roskilde Fjord, U. lactuca was N-limited prior to the large reductions in sewage derived $\mathrm{P}$ (Pedersen \& Borum, 1996), the spring is a critical time period for growth and the establishment of populations of $U$. lactuca. Thus, reductions in nutrient loading, especially $\mathrm{P}$ reductions due to better sewage treatment, may reduce the biomass of fast growing macrophytes (Duarte, 1995), such as Ulva and Cladophora, lessening the nuisance blooms of these macrophytes.

\section{Nitrogen}

As demonstrated above, marine systems are generally believed to be $\mathrm{N}$ limited, although as shown here, $\mathrm{P}$ limitation may occur during spring. However, nearly all estuaries studied to date exhibit $\mathrm{N}$ limitation during the summer. Thus, reductions in $\mathrm{N}$ loading should reduce the biomass of algae produced during the summer and possibly throughout the year. From a recreational viewpoint, summertime reductions in chlorophyll concentrations are desirable.

From an ecosystem viewpoint, reducing summer stocks of phytoplankton should have a large effect on the shading of macrophytes. For example, the depth limits of eelgrass has been shown to be related to N-loading in Danish coastal waters (Borum, 1996). A similar result was obtained in experimental mesocosms where eelgrass beds and mats of drift macroalgae declined in response to phytoplankton shading from increased water column concentrations of chlorophyll resulting from $\mathrm{N}$ enrichment (Taylor et al., 1995). In addition, summertime nutrient reductions should act to reduce the growth of epiphytes, which also act to shade plants (Duarte, 1995). One of the well-known ecosystem consequences of eutrophication is the replacement of submerged vegetation with planktonic communities (Sand-Jensen \& Borum, 1991). The loss of submerged aquatic vegetation can cause enhanced resuspension and decreases in water column clarity with loss of macrophyte cover (Duarte, 1995). Submerged aquatic macrophytes provide important habitat for spawning and cover for fish.

\section{Silicon}

Overenrichment with $\mathrm{N}$ and $\mathrm{P}$ nutrients alters the biogeochemical cycle of $\mathrm{Si}$ allowing for dissolved silicate limitation to occur on a more frequent basis (Conley et al., 1993). These changes in dissolved silicate availability causes the replacement of diatoms by other algae that do not require $\mathrm{Si}$ for growth. The ecosystem consequences of reducing the abundance of 
one of the most important groups of algae on food web structure is not entirely known.

Examinations of nutrient concentrations in 'pristine' river systems yields average concentrations of $7.7 \mu \mathrm{m}$ $\mathrm{N}$ and $0.32 \mu \mathrm{m} \mathrm{P}$ (Meybeck \& Helmer, 1989) and 150 $\mu \mathrm{m}$ for the world average river dissolved silicate concentration (Tréguer et al., 1995). The resultant molar ratio is $24: 470: 1$ for $\mathrm{N}: \mathrm{Si}: \mathrm{P}$ as compared to the Redfield ratio of 16:16:1 (Redfield et al., 1963). Unlike $\mathrm{N}$ or $\mathrm{P}$, dissolved silicate inputs arise primarily from weathering reactions, and with our present knowledge, alteration of the weathering inputs have not been greatly impacted by mans activities. By contrast, the retention of Si has greatly increased with eutrophication (Conley et al., 1983) reducing dissolved silicate concentrations. Thus, changes in nutrient ratios may provide a sensitive indicator for eutrophication.

\section{Conclusions}

Evaluation of historical changes in nutrient loading has revealed that estuarine systems have experienced a 6-50 times increase in the $\mathrm{N}$ load and a 18-180 times increase in the $\mathrm{P}$ load from pristine conditions to present (Figure 2). Given that most management plans for reducing nutrient loads are on the order of a $50 \%$ to $80 \%$ reduction of present loads (Boynton et al., 1995; Kaas et al., 1996), while a large increase over what estuarine systems have received in the past under pristine conditions, will bring most systems near what was experienced at the turn of the century (Figure 2). In terms of what nutrient is limiting in estuaries, it was shown that many estuaries experience $\mathrm{P}$ limitation in spring switching to $\mathrm{N}$ limitation in summer (Table 1). Differences in the biogeochemical cycling of $\mathrm{N}$, and especially that of $\mathrm{P}$ (Caraco et al., 1990) between freshwaters and marine environments contributes to the differences in limiting nutrients in the different environments. The seasonal storage of Fe-bound P during winter and spring (Jensen et al., 1995) and the subsequent temperature-dependent sediment release of $\mathrm{P}$ during summer can account for the seasonal switching in nutrient limitation in estuarine systems.

The construction and implementation of advanced wastewater treatment plants have resulted in reductions in nutrient loading, especially that of $\mathrm{P}$, in a number of estuarine systems world-wide (Boynton et al., 1995; Kaas et al., 1996; Elmgren \& Larsson, 1997). Since only modest changes have occurred in $N$ loading, there have been large increases in the N:P ratio which have the potential to increase the importance of $\mathrm{P}$ relative to $\mathrm{N}$ in the regulation of marine ecosystem production. However, in most estuarine systems studied to date, $\mathrm{N}$ is nearly always limiting in summer, due to benthic-pelagic coupling and the temperaturedependent release of $\mathrm{P}$ from sediments (Nixon et al., 1980). It is only in a few situations that $P$ limitation has been shown to be important year around in estuarine systems (Selmer \& Rydberg, 1993). With these large reductions in $\mathrm{P}$ relative to $\mathrm{N}$ and the shift to higher $\mathrm{N}: \mathrm{P}$ ratios, is it possible to make estuarine systems $\mathrm{P}$ limited year around? While to my knowledge there are no examples from the literature to expect this to occur, modeling studies suggest that year around P limitation is a possibility (Billen \& Garnier, 1997). Evaluation of this question is relevant for example in Danish estuaries (Kaas et al., 1996) and constitute an important area for further scientific study.

Management strategies to implement reductions in $\mathrm{P}$ loading may help oxygen deficits in deep estuaries and reduce fast growing macrophytes, however, reductions in $\mathrm{N}$ are required to reduce summer chlorophyll concentrations and improve conditions for submerged aquatic vegetation. While reductions in $\mathrm{P}$ may limit spring production, it probably will have little effect on summer chlorophyll concentrations. Reductions in $\mathrm{N}$ loading should reduce summer chlorophyll concentrations and improve the conditions for submerged aquatic vegetation and thus improve ecosystem functioning. Finally, if only $\mathrm{P}$ reductions are pursued, that is if we are able to reduce $\mathrm{P}$ such that it is limiting year around in estuarine systems, it would reduce the retention of $\mathrm{N}$ in estuarine systems, and export $\mathrm{N}$ to the N-limited marine systems bordering the estuary systems, thus only exporting the problem. Such a situation occurred upon completion of the Stockholm treatment plant, where algal blooms formerly occurring near the city itself, now occur further out into the archipelago (Brattberg, 1986). These additional $\mathrm{N}$ loads are potentially more severe for the large enclosed coastal seas such as the Baltic. Therefore, arguments for managing only for one of the nutrients, $\mathrm{N}$ or $\mathrm{P}$, to improve the health of coastal ecosystems is problematic.

\section{References}

Andersson, A., S. Hajdu, P. Haecky, J. Kuparinen \& J. Wikner, 1996. Succession and growth limitation of phytoplankton in the Gulf of Bothnian (Baltic Sea). Mar. Biol. 126: 791-801. 
Billen, G., C. Lancelot \& M. Meybeck, 1991. N, P, and Si retention along the aquatic continuum from land to ocean. In R. F. C. Mantoura, J.-M. Martin \& R. Wollast (eds), Ocean Margin Processes in Global Change. John Wiley \& Sons: 19-44.

Billen, G. \& J. Garnier, 1997. The Phison River plume: coastal eutrophication in response to changes in land use and water management in the watershed. Aquat. Microbiol. Ecol. 13: 3-17.

Borum, J., 1996. Shallow waters and land/sea boundaries. In Eutrophication in Coastal Marine Ecosystems, Coastal and Estuarine Studies, Vol. 52, Amer. Geophys. Union, Washington, D. C.: 179-203.

Boynton, W. R., W. M. Kemp \& C. W. Keefe, 1982. A comparative analysis of nutrients and other factors influencing estuarine phytoplankton production. In Estuarine Comparisons, Academic Press: 69-90.

Boynton, W. R., J. H. Garber, R. Summers \& W. M. Kemp, 1995. Inputs, transformations and transport of nitrogen and phosphorus in Chesapeake Bay and selected tributaries. Estuaries 18: 285314.

Brattberg, G., 1986. Decreased phosphorus loading changes phytoplankton composition and biomass in the Stockholm archipelago. Vatten 42: 141-153.

Caraco, N., J. Cole \& G. E. Likens, 1989. Evidence for a sulfate-controlled phosphorus release from sediments of aquatic systems. Nature 341: 316-318.

Caraco, N., J. Cole \& G. E. Likens, 1990. A comparison of phosphorus immobilization in sediments of freshwater and coastal marine systems. Biogeochemistry 9: 277-290.

Chapra, S. C., 1977. Total phosphorus model for the Great Lakes. J. Envir. Eng. Div., ASCE, 103: 147-161.

Cloern, J. E., 1999. The relative importance of light and nutrient limitation of phytoplankton growth: A simple index of coastal ecosystem sensitivity to nutrient enrichment. Aquat. Ecol. 33: 315.

Conley, D. J. \& T. C. Malone, 1992. Annual cycle of dissolved silicate in Chesapeake Bay: Implications for the production and fate of phytoplankton biomass. Mar. Ecol. Prog. Ser. 81: 121-128.

Conley, D. J., C. L. Schelske \& E. F. Stoermer, 1993. Modification of silica biogeochemistry with eutrophication in aquatic systems. Mar. Ecol. Prog. Ser. 101: 179-192.

D’Elia, C. F., J. G. Sanders \& W. R. Boynton, 1986. Nutrient enrichment studies in a coastal plain estuary: Phytoplankton growth in large-scale continuous cultures. Can. J. Fish. aquat. Sci. 43: 397-406.

D'Elia, C. F., 1987. Too much of a good thing. Nutrient enrichment of Chesapeake Bay. Environment 29: 6-11, 30-33.

Del Amo, Y., O. Le Pape, P. Tréguer, B. Quéguiner, A. Ménesguen \& A. Aminot, 1997. Impacts of high-nitrate freshwater inputs on macrotidal ecosystems. I. Seasonal evolution of nutrient limitation for the diatom-dominated phytoplankton of the Bay of Brest (France). Mar. Ecol. Prog. Ser. 161: 213-224.

Duarte, C. M., 1995. Submerged aquatic vegetation in relation to different nutrient regimes. Ophelia 41: 87-112

Elser, J. J., E. R. Marzolf \& C. R. Goldman, 1990. Phosphorus and nitrogen limitation of phytoplankton growth and the freshwaters of North America: A review and critique of experimental enrichments. Can. J. Fish. aquat. Sci. 47: 1468-1477.

Elmgren, R. \& U. Larsson, 1997. Himmerfjärden. Changes in a nutrient loaded coastal ecosystem in the Baltic. Swedish Environmental Protection Agency, Stockholm: 197 pp. (in Swedish).

Gallegos, C. L. \& T. E. Jordan, 1997. Seasonal progression of factors limiting phytoplankton pigment biomass in the Rhode River estuary, Maryland (U.S.A.). II. Modeling N versus P limitation. Mar. Ecol. Prog. Ser. 161: 199-212.
Granéli, E., K. Wallström, U. Larsson, W. Granéli \& R. Elmgren, 1990. Nutrient limitation of primary production in the Baltic Sea Area. Ambio 19: 142-151.

Hecky, R. E. \& P. Kilham, 1988. Nutrient limitation of phytoplankton in freshwater and marine environments. A review of recent evidence on the effects of enrichment. Limnol. Oceanogr. 33: 796-822.

Hedin, L. O., J. J. Armesto \& A. H. Johnson, 1995. Patterns of nutrient loss from unpolluted, old-growth temperate forests: Evaluation of biogeochemical theory. Ecology 76: 493-509.

Howarth, R. W., 1988. Nutrient limitation of net primary production in marine ecosystems. Ann. Rev. Ecol. Sys. 19: 89-110.

Howarth, R. W., R. Marino, J. Lane \& J. J. Cole, 1988. Nitrogen fixation in freshwater, estuarine and marine ecosystems. 1. Rates and importance. Limnol. Oceanogr. 33: 669-687.

Howarth, R. W., D. Swaney, R. Marino, T. Butler \& C. R. Chu, 1995. Turbulence does not prevent nitrogen fixation by plankton in estuaries and coastal seas (reply to the comment of Paerl et al.). Limnol. Oceanogr. 40: 639-643.

Jensen, H. S., P. B. Mortensen, F. Ø. Andersen, E. Rasmussen \& A. Jensen, 1995. Phosphorus cycling in a coastal marine sediment, Aarhus Bay, Denmark. Limnol. Oceanogr. 40: 908-917.

Kaas, H., F. Møhlenberg, A. Josefson, B. Rasmussen, D. KrauseJensen, H. S. Jensen, L. Svendsen, J. Windolf, A. L. Middelboe, K. Sand-Jensen \& M. F. Pedersen, 1996. Marine områder. Danske fjorde - status over miljøstand, årsagssammenhænge og udvikling. Danish Ministry of the Environment Rapport Nr. 179, Roskilde, Denmark: 205 pp. (in Danish).

Larsson, U., R. Elmgren \& F. Wulff, 1985. Eutrophication and the Baltic Sea: Causes and consequences. Ambio 14: 9-14.

Maestrini, S. Y., M. Balode, C. Béchemin, I. Purina \& C. Vérite, 1997. Nutrients limiting the algal growth potential (AGP) in the Gulf of Riga, eastern Baltic Sea, in spring and early summer 1996. La mer 35: 49-68.

Mallin, M. A. \& H. W. Paerl, 1994. Commentary on primary productivity and nutrient limitation in the Neuse River Estuary, North Carolina, U.S.A. Mar. Ecol. Prog. Ser. 111: 311-312.

Malone, T. C., W. M. Kemp, H. W. Ducklow, W. R. Boynton, J. H. Tuttle \& R. B. Jones. 1986. Lateral variation in the production and fate of phytoplankton in a partially stratified estuary. Mar. Ecol. Prog. Ser. 32: 149-160.

Malone, T. C., D. J. Conley, T. R. Fisher, P. M. Glibert, L. W. Harding, Jr. \& K. G. Sellner, 1996. Scales of nutrient limited phytoplankton productivity in Chesapeake Bay. Estuaries 19: 371-385.

Meybeck, M. \& R. Helmer, 1989. The quality of rivers: from pristine stage to global pollution. Palaeogeogr. Palaeoclimatol. Palaeoecol. 75: 283-309.

Nixon S. W., J. R. Kelly, B. N. Furnas, C. A. Oviatt \& S. S. Hale, 1980. Phosphorus regeneration and the metabolism of coastal marine bottom communities. In K. R. Tenore \& B. C. Coull (eds), Marine Benthic Dynamics. Univ. S. Carolina Press, Columbia, SC: 219-242.

Nixon, S.W. et al. (15 co-authors), 1996. The fate of nitrogen and phosphorus at the land-sea margin of the North Atlantic Ocean. Biogeochemistry 35: 141-180.

Nixon, S. W., 1995. Coastal marine eutrophication: A definition, social causes and future concerns. Ophelia 41: 199-219.

Nixon, S. W., 1997. Prehistoric nutrient inputs and productivity in Narragansett Bay. Estuaries 20: 253-261.

Oviatt, C., P. Doering, B. Nowicki, L. Reed, J. Cole \& J. Frithsen, 1995. An ecosystem level experiment on nutrient limitation in temperate coastal marine environments. Mar. Ecol. Prog. Ser. 116: $171-179$. 
Paerl, H. W., J. L. Pickney \& S. A. Kucera, 1995. Clarification of the structural and functional roles of heterocysts and anoxic microzones in the control of pelagic nitrogen fixation. Limnol. Oceanogr. 40: 634-638.

Pedersen, M. F. \& J. Borum, 1996. Nutrient control of algal growth in estuarine waters. Nutrient limitation and the importance of nitrogen requirements and nitrogen storage among phytoplankton and species of macroalgae. Mar. Ecol. Prog. Ser. 142: 261-272.

Pennock, J. R. \& J. H. Sharp, 1994. Temporal alternation between light- and nutrient-limitation of phytoplankton in a coastal plain estuary. Mar. Ecol. Prog. Ser. 111: 275-288.

Prairie, Y. T., C. M. Duarte \& J. Kalff, 1989. Unifying nutrientchlorophyll relationships in lakes. Can. J. Fish. aquat. Sci. 46: 1176-1182.

Redfield, A. C., B. H. Ketchum \& F. A. Richards, 1963. The influence of organisms on the composition of sea-water. In M. N. Hill (ed.), The Sea. John Wiley \& Sons, New York: 12-37.

Rysgaard, S., P. B. Christensen \& L. P. Nielsen, 1995. Seasonal variation in nitrification and denitrification in estuarine sediment colonized by benthic microalgae and bioturbating infauna. Mar. Ecol. Prog. Ser. 126: 111-121.

Ryther, J. H. \& W. M. Dunstan, 1971. Nitrogen, phosphorus, and eutrophication in the coastal marine environment. Science 171: 1008-1013.

Sand-Jensen, K. \& J. Borum, 1991. Interactions among phytoplankton, periphyton, and macrophytes in temperate freshwaters and estuaries. Aquat. Bot. 41: 137-175.

Selmer, J.-S. \& L. Rydberg, 1993. Effects of nutrient discharge by river water and waste water on the nitrogen dynamics in the archipelago of Göteborg, Sweden. Mar. Ecol. Prog. Ser. 92: 119-133.

Schindler, D. W., 1974. Eutrophication and recovery in experimental lakes: implications for lake management. Science 184: 897-899.

Seitzinger, S. P., 1988. Denitrification in freshwater and coastal marine ecosystems: Ecological and geochemical significance. Limnol. Oceanogr. 33: 702-724.

Stålnacke, P., A. Grimvall, K. Sundblad \& A. Tonderski, 1998. Estimation of riverine loads of nitrogen and phosphorus to the Baltic Sea, 1970-1993. J. Envir. Monit. Assem.

Taylor, D., S. Nixon, S. Granger \& B. Buckley, 1995. Nutrient limitation and the eutrophication of coastal lagoons. Mar. Ecol. Prog. Ser. 127: 235-244.

Tréguer, P., D. M. Nelson, A. J. van Bennekom, D. J. DeMaster, A. Leynaert \& B. Quéguiner, 1995. The silica balance in the world ocean: a reestimate. Science 268: 375-379.

Vollenweider, R. A., 1976. Advances in defining critical loading levels of phosphorus in lake eutrophication. Mem. Ist. ital. Idrobiol. 33: 53-83.

Wassmann, P., 1991. Dynamics of primary production and sedimentation in shallow fjords and polls of western Norway. Oceanogr. mar. Biol. Annu. Rev. 29: 87-154.

Webb, K. L., 1988. Comment on "Nutrient limitation of phytoplankton growth in brackish coastal ponds" by Caraco, Tamse, Boutros and Valiela (1987). Can. J. Fish. aquat. Sci. 45: 380-381. 